\title{
Decision-making Styles of Individualist and Collectivist Automobile Consumers in Australia
}

\author{
Tahmid Nayeem ${ }^{1}$ \\ ${ }^{1}$ Swinburne University of Technology, Melbourne, Australia \\ Correspondence: Tahmid Nayeem, Swinburne University of Technology, Australia. Tel: 61-3-9215-7702. E-mail: \\ tnayeem@swin.edu.au
}

Received: May 15, 2012 Accepted: June 28, 2012 Online Published: August 16, 2012

doi:10.5539/ijbm.v7n16p44 URL: http://dx.doi.org/10.5539/ijbm.v7n16p44

\begin{abstract}
This study investigates the relationship between individualism-collectivism and consumer decision-making styles applied to the purchase of automobiles. An adapted version of the widely used Consumer Styles Inventory (Sproles \& Kendall, 1986) was used to measure consumer decision-making styles. Based on a sample of 202 respondents from Australian individualist and collectivist backgrounds, exploratory and confirmatory factor analysis were conducted on Sproles and Kendall's (1986) CSI adapted for high involvement purchases. Mean differences between the two cultural backgrounds were assessed via MANCOVA. Results indicated that individualists and collectivists significantly differed on 'brand conscious' and 'confused by overchoice' decision making styles, with collectivists scoring significantly higher. There were no differences in the perfectionist, high quality conscious; price conscious and habitual/brand loyal decision-making styles. The paper also discusses how automobile companies could develop suitable marketing strategies for individualist and collectivist consumers in Australia.
\end{abstract}

Keywords: CSI, individualism-collectivism, automobiles, consumer decision-making styles

\section{Introduction}

Until recently, the impact of culture on consumer behaviour was not well understood (de Mooij, 2010). Ignoring culture's influence on consumer behaviour has led to enormous losses for many companies (Bond et al., 2004). Consumers from different cultural backgrounds have different needs and values that give rise to variation in product and brand preferences (Manrai, Lascu, Manrai, \& Babb, 2001). They may adopt different purchasing behaviours/styles even for the same product (de Mooij, 2010). In some cultures, it is important to follow what society suggests as suitable and meaningful selection criteria for product purchases (Blodgett, Bakir, \& Rose, 2008). This is particularly the case for specialty/high involvement purchases such as automobiles, which are very important to consumers' daily lives and often convey social meaning such as personality, status, and prestige (Belk, Kenneth, \& Robert, 1982).

The current study focuses on automobiles as a basis for investigating cultural differences in decision making styles for high involvement purchases. Automobiles were chosen for a number of reasons: they are an infrequent purchase, necessary resource, and involve risk, in that there is a large investment involved; therefore information, time and extensive research is required (Satish \& Bharadhwaj, 2010). Major car manufacturers provide a full range of car model types, e.g., sports, sedan, SUV, van etc., and the decision regarding vehicle type is most likely to be made prior to making a brand decision. As a result, consumers usually have a clear vehicle type preference that is not influenced by the immediate purchase environment. Therefore, the purchase of an automobile is usually a rational purchase behaviour, guided by a decision making process (Dann \& Dann, 2003; Veroplanken \& Herabadi, 2001). This research aims to establish the similarities and differences between individualist and collectivist consumers in relation to automobile purchases.

\section{Theory and Hypotheses}

\subsection{Cultural Background: Individualism-collectivism}

The study of individualism-collectivism is concerned with the relationship of the individual to the collective (Singelis, Triandis, Bhawuk, \& Gelfand, 1995; Triandis, 2008). Individualists believe that the Self is the basic unit of survival, while collectivists believe that survival lies within the group or several groups. According to 
Triandis (1995), there are four major dimensions to the construct of individualism-collectivism: (1) the definition of 'self', (2) personal and communal goals, (3) cognitions that focus on norms, obligations and duties, and (4) emphasis on relationships. These four dimensions have been widely used in previous cross-cultural consumer behaviour studies (see, for example, Manrai \& Manrai, 1996; de Mooij, 2004) and provide an effective basis for comparison between cultural groups (Liu \& McClure, 2001). The discussion that follows uses these four dimensions to discuss differences between the consumer decision making styles of individualists and collectivists.

Individualists define the Self independently of groups (Hui, 1998). Their independent view of the Self highlights separateness, internal attributes and uniqueness. Personal goals are given priority over communal goals or interests. Therefore, in individualist cultures, identity is defined by what one owns, experiences, and accomplishes. Individualists generally do not feel strong obligations towards family or community. Their own needs are very important and, as such, they are usually more focused on fulfilling their own interests, which they place above those of the group (Kim, Forsythe \& Moon, 2002). They take care of themselves and downplay the needs of the group if they conflict with personal desires (Wagner \& Moch 1986). In contrast, people from collectivist cultures generally hold an interdependent view of the Self that highlights relationships, social context, and connectedness with others in society. Thus, in collectivist cultures, identity is defined by one's relationship to others within the community or in-group (Triandis, 1995). Collectivists tend to sacrifice personal goals for those of the in-group and emphasise harmony, interdependence and concern for the collective (Triandis, 1995). Therefore, collectivists are more focused on others and making sure that behaviours, expressions and desires fit into what is welcomed by and acceptable to the collective (Kim et al., 2002).

Hofstede's work (1980, 1983, 1984, \& 2001) has established that the United States, Australia, the United Kingdom (UK) and other Western countries cluster toward the individualist end of the continuum, whilst India, Pakistan, Thailand, Hong Kong, Taiwan and other Asian countries cluster toward the collectivist end (Hofstede, 2001). According to Hofstede, every national population shares a national culture. 'National culture' is the only culture within a nation, culturally distinguishing the population of one nation from the population of another (Hosfstede, 2001). McSweeney (2002) critiqued Hofstede's model of national cultural differences, arguing that assumption of equating nation with culture provided a limited representation of culture. McSweeney suggested that alternative conceptions of culture should consider multiple, non-national influencing factors. Perhaps the most significant alternative view to Hofstede's national culture to have emerged is the view that cultural dimensions such as individualism and collectivism operate in all societies, and individualistic and collectivistic tendencies can be found within any given culture at different levels (Ho \& Chiu, 1994; Triandis, 1995). While Hofstede's view suggests that Eastern cultures are collectivistic and Western cultures are individualistic, the alternative view suggests that Easterners and Westerners do not necessarily differ from one another on these dimensions.

\subsubsection{Individualism-collectivism and Consumer Decision Making}

The individualism-collectivism dimension has been applied in a variety of consumer marketing contexts, for example, studies of advertising (Alden, Hoyer, \& Lee, 2003; Gregory \& Munch, 1997), complaint behaviour (Liu \& McClure, 2001; Mattila \& Patterson, 2004), global brand strategies (Roth, 1995), consumer innovativeness (Steenkamp, Hofstede, \& Wedel, 1999), impulsive buying (Kacen \& Lee, 2002), persuasion (Aaker \& Maheswaran, 1997), and ethical decision-making (Blodgett et al., 2008). However, to date, little research has examined how consumer decisions are made in different cultures, including the type of decision making styles adopted (Soars, Farhangmehr, \& Shoham, 2007). It is useful to identify consumer decision-making styles in different cultural groups to segment consumers into profitable clusters (Lysonski, Durvasula, \& Zotos, 1996).

There have been some attempts to identify differences in decision-making between Eastern and Western cultures in past research (Omar, Ali, Hussin, \& Rahim, 2009). For example, decision-making in collectivist cultures is generally a group activity (Doran, 2002). Collectivists rely on word-of-mouth communication such as informal channels due to the high contact rate among group members (Gurhan-Canli \& Maheswaran, 2000). They usually follow tradition and are less likely to show interest in innovation. New things are often viewed with great scepticism and may only be acknowledged after long resistance (Cowley, 2002). On the other hand, decision-making in individualist cultures is an independent activity (Gurhan-Canli \& Maheswaran, 2000) and innovation is more readily accepted (Leo, Bennett, \& Hartel, 2005).

\subsubsection{Consumer Decision-making Styles and the Consumer Styles Inventory (CSI)}

The investigation of consumer decision-making has a long tradition in marketing and consumer behaviour 
research (Bauer, Sauer, \& Becker, 2006). The most commonly used measure of consumer decision-making styles in cross-cultural studies is Sproles and Kendall's (1986) Consumer Styles Inventory (CSI) (Hanzaee \& Aghasibeig, 2008). Sproles (1983) argued that there are fundamental styles that all consumers apply to shopping and buying. These styles included brand, price, and quality consciousness, and provided a conceptual framework for describing consumer decision-making styles. Sproles and Kendall (1986) later developed a revised model consisting of eight consumer decision-making styles based on cognitive and personality characteristics. Each of these styles independently characterises a fundamental intellectual approach to consumption (Hanzaee \& Aghasibeig, 2008). Sproles and Kendall's eight consumer decision-making styles are shown in Table 1.

Table 1. Consumer decision-making styles

\begin{tabular}{|c|c|}
\hline $\begin{array}{l}\text { Consumer } \\
\text { decision-making styles }\end{array}$ & Definition \\
\hline $\begin{array}{l}\text { Perfectionist, high } \\
\text { quality conscious }\end{array}$ & $\begin{array}{l}\text { Consumer has specific ideas about best quality products and consistently looks for } \\
\text { these qualities. Characterised by a consumer's search for the very best quality in } \\
\text { products. }\end{array}$ \\
\hline Brand conscious & $\begin{array}{l}\text { Consumer associates quality with higher priced brands and is expected to buy } \\
\text { expensive, well-known brands, believing that the higher the price, the better the } \\
\text { quality }\end{array}$ \\
\hline Recreational & $\begin{array}{l}\text { Characterises people who are likely to shop just for fun/leisure and find shopping } \\
\text { pleasant. Recreational shoppers engage themselves in the purchase situation, since } \\
\text { they like to know more about the product as a form of enjoyment }\end{array}$ \\
\hline Price conscious & $\begin{array}{l}\text { Consumer consistently searches for sales, bargains and lower-priced products. } \\
\text { These consumers exhibit price and value for money consciousness. }\end{array}$ \\
\hline Impulsive & $\begin{array}{l}\text { Consumer does not plan their shopping, and is not concerned with how much they } \\
\text { spend or with value for money. Impulsive buyers do not reflect on their thinking } \\
\text { and are very emotionally attracted to the object. }\end{array}$ \\
\hline $\begin{array}{l}\text { Confused by } \\
\text { overchoice }\end{array}$ & $\begin{array}{l}\text { Consumer is confused and overwhelmed with too much product information } \\
\text { and/or too many product choices. Characterises consumers who are confused } \\
\text { about the quality of different brands and by the information available. }\end{array}$ \\
\hline Habitual/brand loyal & $\begin{array}{l}\text { Consumer tends to consistently stick with the same brand of product. } \\
\text { Characterises shoppers who have favourite brands and stores and use these } \\
\text { habitually. }\end{array}$ \\
\hline $\begin{array}{l}\text { Novelty fashion } \\
\text { conscious }\end{array}$ & $\begin{array}{l}\text { Consumer is characterised as a novelty seeker. They find seeking out new things } \\
\text { pleasurable and exciting. }\end{array}$ \\
\hline
\end{tabular}

Although the CSI is commonly used measure of consumer decision-making styles in cross-cultural studies (Hanzaee \& Aghasibeig, 2008) it has some limitations. Firstly, it is unclear whether the CSI, validated with student samples, is suitable for use with broader consumer groups (Leo et al., 2005). Secondly, the factor structure of the CSI is unstable, suggesting poor construct validity (Durvsula, Lysonski, \& Andrews, 1993; Radder, $\mathrm{Li}, \&$ Pietersen, 2006). The number of factors varies across studies and reliability coefficients are in the low to average range (Mitchell \& Bates, 1998). Finally, work is needed to develop scales that are culture- and product-specific (Bauer et al., 2006).

In the current study the CSI was administered to an adult sample in the general population with items reworded to focus on a specific product type: automobiles. The aim was to use the CSI to examine the influence of cultural background (individualism-collectivism) on consumer decision making-styles in relation to automobile purchases. Hypotheses regarding the relationship between individualism-collectivism and consumer decision making styles are outlined below.

\subsection{Consumer Decision-making Styles and Individualism-collectivism in Relation to Automobile Purchases}

\subsubsection{Perfectionist, High Quality Conscious Decision-making Style}

Quality conscious consumers search for the best quality products by shopping carefully and systematically 
(Sproles \& Kendall, 1986). Doran (2002) noted that people from collectivist cultures are more likely to be quality conscious, because they are more anxious about the hierarchy among people in society (Hofstede, 2001). Social recognition and status are very important to collectivists, and they are keen to establish their superiority at the familial, societal or national level (Ackerman \& Tellis, 2001). High quality products are associated with status and social recognition, which may influence consumers' purchase decisions (Phau, Teah, \& Lee, 2009). Buying high quality automobiles could be one way that collectivists portray a superior image of themselves in their society.

$\mathrm{H}_{1}$ : Collectivists are more perfectionist, high quality conscious consumers than individualists.

\subsubsection{Brand Conscious Decision-making Style}

Collectivists are copious luxury consumers and are developing into the world's largest brand name luxury goods consumer market (Phau et al., 2009). Consumers learn a great deal from their cultural background (Hofstede, 2001), and expensive brands of products have become symbols for high status (Wong \& Ahuvia, 1998). For example, driving an imported car in some collectivist countries creates an image of prestige. Collectivists have a tendency to prefer imported brands to commodities produced in their own country (Watson \& Wright, 2000). Collectivists may purchase an automobile, not just to satisfy themselves, but society as a whole.

$\mathrm{H}_{2}$ : Collectivist consumers are more brand conscious than individualist consumers.

\subsubsection{Recreation Conscious Decision-making Style}

Recreation conscious consumers shop for leisure, fun, or pleasure (Sproles \& Kendall, 1986). Collectivist consumers involve family members, friends and colleagues in the decision-making process and generally prefer to shop in groups (Doran, 2002). As such, searching for product information may be an enjoyable activity for them as they can connect with others during the process. In contrast, searching for product information may be less recreational for individualist consumers because they tend to rely on their own opinions, preferences, tastes and choices (Triandis, 1995). In the context of buying an automobile, individualist consumers will most likely consult only a few family members before buying a car. In contrast, collectivist consumers will most likely invite members of their in-group to view the cars and express their opinions. They may find a member of their social network who sells cars, fostering a personal relationship with the dealer by sharing personal details to establish rapport.

$\mathrm{H}_{3}$ : Collectivist consumers are more recreation conscious than individualist consumers.

\subsubsection{Price Conscious Decision-making Style}

Price conscious consumers are characterised by an 'unwillingness' to pay a higher price for products and an exclusive focus on paying low prices (Sproles \& Kendall, 1986). As discussed above, collectivist consumers believe that one's position in society is determined largely by economic advancement or displays of wealth (Miller \& Volker, 1985) and are likely to seek products that convey status and prestige (Phau \& Lau, 2001). Therefore, collectivist consumers are likely to invest more money in high involvement purchase decisions, such as automobiles, and to be less price conscious. In individualist cultures people conspicuously consume luxury/expensive products because they 'want to' (i.e., products reflect personal preferences), not because they feel they 'have to' in order to conform or gain social recognition (Wong \& Ahuvia, 1998). Therefore, automobiles do not have the same symbolic meanings for individualist consumers, and they may be more inclined to seek economical purchases rather than focusing on displays of wealth.

$\mathrm{H}_{4}$ : Individualist consumers are more price conscious than collectivist consumers.

\subsubsection{Impulsive Buying Decision-making Style}

Impulsive buying behaviour is a widely recognised phenomenon in individualist countries, creating up to $80 \%$ of all purchases in certain low involvement purchase categories (Hassay \& Smith, 1996). Mogelonsky (1998) reported that in the United States an estimated $\$ 4.2$ billion in annual volume was generated by impulse purchases of items such as candy and magazines. This suggests that individualist consumers commonly adopt an impulsive decision-making style when purchasing low involvement products, but the question remains as to whether they are also impulsive when purchasing high involvement products.

Few studies have examined impulse buying in collectivist countries (Vohs \& Faber, 2007). Kacen and Lee (2002) noted that collectivist consumers are less likely to engage in impulse buying than are individualist consumers because they evaluate the effect of their behaviour on in-group members and thus spend more time weighing up potential negative consequences before making a purchase (Triandis, 2008). As such, collectivists may be more rational than impulsive (Kacen \& Lee, 2002). 
$\mathrm{H}_{5}$ : Individualist consumers are more impulsive than collectivist consumers.

\subsubsection{Confused by Overchoice Decision-making Style}

Consumers are confused by overchoice when they have too much information, making it harder for them to identify the 'right' product and reach a decision (Durvasula et al., 1993). Collectivists rely heavily on social networks for information (Doran, 2002), seeking advice from reference groups such as their family members and friends (de Mooij, 2004). In contrast, individualist consumers do less directed searching, but have greater internal knowledge due to long-term exposure in developed countries to information such as vehicle safety, economy, luxury and high performance vehicles. Collectivists, such as Asian-born consumers, may try to collect all this information within a short timeframe, before purchasing the automobile. This volume of information may be difficult to synthesise, leading to greater confusion among the various brands.

$\mathrm{H}_{6}$ : Collectivist consumers are more confused by overchoice than individualist consumers.

\subsubsection{Habitual/brand Loyal Decision-making Style}

Habitual/brand loyal consumers form habitual purchasing behaviours and remain with their favourite brands or stores (Sproles \& Kendall, 1986). Brand loyalty can be seen as a risk reduction strategy in that it removes the need to search for new information (Singh, 2006). Collectivists utilise reference groups as information sources which may eliminate certain brand preferences, therefore they do not need to choose the same brand over and over to minimise risk. Research by Doran (2002) showed that US (individualist) consumers are more brand loyal and concerned about risk than Thai (collectivist) consumers. This supports the idea of a connection between risk reduction and brand loyalty.

$\mathrm{H}_{7}$ : Individualist consumers are more habitual/brand loyal than collectivist consumers.

\section{Method}

\subsection{Participants}

Participants consisted of 202 men (46.5\%) and women (53.5\%) from individualist (Australian-born) or collectivist (Asian-born) backgrounds that had purchased a car within the last 12 months. Twelve months was expected to be a reasonable time frame for recalling consumer decision-making styles (Park \& Kim, 2003). In addition, given that the research questions are framed around comparing the consumer decision-making styles of Australian individualist and collectivist consumers, these criteria also had to be met. The sample size was 100 participants per cultural group, which was the requirement for planned statistical analyses (Kline, 2005).

The sampling technique employed was non-probabilistic sampling; the researcher specified the characteristics of the population of interest (Australian-born and Asian-born consumers who had purchased a car within the last twelve months) and then located individuals who matched the needed characteristics. The researcher then recruited 100 participants per cultural grouping, Australian-born and Asian-born, who met the inclusion criteria and were willing to participate and included them in the research study. The participants were recruited through 12 motor vehicle dealerships in Melbourne, Australia. A total of $49 \%$ of participants were locally-born Australians (individualists), and 51\% were Asian-born (collectivists). Among the collectivist participants, 49\% were born in South Asia and 51\% were born in South-East Asia.

\subsection{Measures}

(1) Demographic Questions: Demographic information such as age, gender, education, marital status, income and number of years driving was collected for the purpose of describing the sample and identifying any differences in the demographic characteristics of individualist and collectivist subgroups so that these could be controlled in the main analyses.

(2) Consumer Styles Inventory (CSI; Sproles \& Kendall, 1986): The CSI is an established scale consisting of 45 statements that assess eight consumer decision making styles. Participants rated their agreement with each statement on a six-point scale ranging from "strongly disagree" (1) to "strongly agree" (7). For the purpose of this research, original item wording was altered to be specific to automobile purchases. A sample item is, "A car does not have to be perfect, or the best, to satisfy me".

(3) Cultural Values Scale (CVS; Singelis et al., 1995): This scale was used to confirm that locally-born and Asian-born Australians differed in their endorsement of collectivist versus individualist values. The CVS consists of 32 statements and consists of two subscales, individualism and collectivism, each having 16 items. Participants rated their agreement/disagreement with each statement on a 6-point scale ranging from "strongly disagree" (1) to "strongly agree" (7). A sample item is, "My happiness depends very much on the happiness of those around me". 


\subsection{Procedure}

Participants were informed about the project via a written project information statement. Consent was implied by the return of a completed questionnaire. Participants completed the questionnaire at a location and time that was suitable for them, and returned questionnaires by mail in pre-paid envelopes, ensuring complete anonymity. The survey took approximately 30 minutes to complete. Surveys were either collected as they were completed, or were returned by mail. A post-paid envelope was provided with each questionnaire. Among the prerequisites that had to be met by respondents in order to be eligible to participate in the research were that they had to (a) be at least 18 years of age, (b) be holders of a current driver's license, and (c) have purchased a car within the past twelve months. Out of 422 surveys that were distributed for this study, 212 were returned, of which ten incomplete surveys were discarded. These ten incomplete surveys were discarded because more than $10 \%$ of the results were missing values. For thorough estimates and analyses, only those surveys that were filled out correctly and completely were used for this study ( $49 \%$ of the total distribution).

\section{Results}

\subsection{Preliminary Analyses: Scale Reliability and Measurement Structure Consistency}

An Exploratory Factor Analysis (EFA) was conducted on the CSI items using the calibration sample $(\mathrm{N}=202)$ with maximum likelihood extraction and oblique rotation (OBLIMIN). The various indications of the factorability of the scale were good and appropriate: KMO was .711, and the Barlett test of sphericity, which indicated a significance level of $\mathrm{p}<.001$, also showed that the factor analysis was appropriate. Six factors were generated: Perfectionist; Brand; Confused by overchoice; Price; Habitual, brand loyal; and Recreational conscious. The impulsiveness and novelty fashion conscious factors from the original CSI was not confirmed in the present study. The solution showed that all factors were above the elbow, or break, in the plot, and that these factors explained the most variance (Byrne, 2001). This satisfactory factorial structure was achieved by removing eight items to re-specify the factor model and a new factor solution was derived after the removal of each item, because maximum likelihood extraction is based on shared variance (Byrne, 2001). Item loadings and scale reliabilities (Cronbach's alpha) are summarised in Table 3. The value of the loadings of 0.50 was used as a guideline in the factor analysis (see Nunally, 1978).

Table 3. Factor loadings and reliabilities for adapted CSI

\begin{tabular}{lc}
\hline Factor and Items & $\begin{array}{c}\text { loadings } \\
\text { Cronbach's } \\
\text { alpha }\end{array}$ \\
\hline Factor 1 Perfectionist, high quality conscious & .567 \\
Getting a very good quality car is very important to me & -.544 \\
I really don't give my car purchases much thought or care* & -.661 \\
Investigating new brands of cars is generally a waste of time* & -.644 \\
I shop quickly for cars, buying the first car or brand I find that seems good enough* & .544 \\
The most advertised car brands are usually very good choices & .553 \\
When it comes to buying a car, in general, I usually try to buy the best overall quality & \\
Factor 2 Confused by overchoice & .582 \\
I should plan my shopping for cars more carefully than I do & .740 \\
All the information I get on different cars confuses me & .562 \\
It's hard to choose which dealers to shop at for cars & .611 \\
The more I learn about cars, the harder it seems to choose the best & .528 \\
There are so many car brands to choose from that often I feel confused & \\
Factor 3 Recrational shopping conscious & .531 \\
I am the kind of a person who would try a new make of car & -.508 \\
I would rather wait for others to try a new dealer than try it myself in making my & \\
purchase* & .505 \\
I would buy a new or different brand of car just to see what it is like & .588 \\
Going shopping for cars is an enjoyable activity for me & .682 \\
I enjoy shopping for cars just for the fun of it & .726 \\
I take advantage of the first opportunity to find out more about a new dealer selling a \\
car that I would like to purchase
\end{tabular}


Factor 4 Price conscious

I prefer to buy cars at sale prices

When shopping for cars, I look carefully to find best value for money

When buying a car, I do not want to make a careless purchase I later wish I had not

When shopping for cars, I take the time to shop carefully for best buys

I am willing to change brands when buying a new car

When buying a car, I carefully watch how much I spend

When it comes purchasing cars, I try to get the very best or perfect choice

A car does not have to be perfect, or the best, to satisfy me*

I go to the same dealer each time I shop for cars

The higher the price of a car, the better its quality

The lower price cars are usually my choice*

The more expensive car brands are usually my choice

I have favourite car brands I buy over and over

I make a special effort to choose the very best quality cars $\quad .538$

Shopping around dealers wastes my time

Once I choose a car brand I like, I stick with it

*reversed score

Confirmatory factor analyses (CFA) was conducted for each consumer decision-making style factor by running single factor congeneric models. The indices of goodness-of-fit showed that all the models were satisfactory. Consistent with past research (see Hafstrom, Chae, \& Chung, 1992; Hiu et al., 2001), only scales with Cronbach's alpha of .60 and above were accepted for further analysis. Therefore, recreational was excluded from further analysis due to low reliability. Table 4 summarizes the goodness of fit of the models used for measurement and the Cronbach's alpha for all the scales.

Table 3. Goodness-of-fit for measurement models

\begin{tabular}{lccccccc}
\hline Factor & CMIN/DF & GFI & AGFI & TLI & CFI & RMSEA & SRMR \\
\hline Perfectionist & 2.350 & 0.99 & 0.94 & 0.95 & 0.99 & 0.05 & 0.03 \\
Brand & 1.746 & 0.98 & 0.95 & 0.94 & 0.96 & 0.05 & 0.03 \\
Confused & 1.304 & 0.99 & 0.97 & 0.99 & 1.00 & 0.04 & 0.02 \\
Price & 1.599 & 0.98 & 0.95 & 0.95 & 0.97 & 0.05 & 0.04 \\
Habitual & 1.856 & 1.00 & 0.98 & 1.00 & 1.00 & 0.05 & 0.02 \\
\hline
\end{tabular}

\subsection{Cultural Background: Differences between Individualists and Collectivists}

Table 4 shows the means and standard deviations for individualism and collectivism within each cultural group.

Table 4. Individualism and collectivism by cultural group

\begin{tabular}{lcccc}
\hline & \multicolumn{2}{c}{ Australian-born } & \multicolumn{2}{c}{ Asian-born } \\
\hline Cultural Background & Mean & SD & Mean & SD \\
Individualism & 4.40 & .76 & 4.39 & .66 \\
Collectivism & 4.18 & .67 & 4.93 & .83 \\
\hline
\end{tabular}

An independent samples t-test was performed, with country of birth (Australia versus Asia) as the independent variable and individualism and collectivism as the dependent variables. Results indicated that Asians scored 
significantly higher than Australians, $t(192.042)=-7.045, p<.001$ (mean difference $=.766)$. However, there was no difference for individualism, $t(200)=.14, p=.89$.

To test for differences in the demographic characteristics of the two groups (due to sampling), chi-square tests were performed with country of birth as the independent variable and age, gender, education, marital status, income and number of years driving as the dependent variables (Bonferroni adjustment was used to correct for Type 1 error). Results revealed that Australian-born and Asian-born consumers differed on the following demographic variables: age $\chi(5)=25.81, p<.001$, education $\chi(5)=36.61, p<.001$ and $\operatorname{sex} \chi(6)=26.37, p$ $<.001$. Demographic variables that significantly differed between the groups and were correlated with the consumer decision-making styles were subsequently controlled (included as covariates) in the hypotheses testing analyses.

To test for differences in the demographic characteristics of the two groups (due to sampling), chi-square tests were performed with country of birth as the independent variable and age, gender, education, marital status, income and number of years driving as the dependent variables (Bonferroni adjustment was used to correct for Type 1 error). Results revealed that the subgroups differed on age $\chi(5)=25.81, p<.001$, education $\chi(5)=36.61$, $p<.001$ and $\operatorname{sex} \chi(6)=26.37, p<.001$. Demographic variables that significantly differed between the groups, and were correlated with the consumer decision-making styles, were included as covariates in the main analyses.

\subsection{Hypotheses Testing: Comparison of Means for CSI Factors for Individualists and Collectivists}

A multivariate analysis of covariance was performed on the five remaining consumer decision-making styles such as perfectionist, high quality conscious, confused by overchoice, brand conscious, rational, price conscious, and habitual, brand loyal decision-making styles. Adjustment was made for three covariates: age, education and income. The independent variable was cultural background (Australian-born and Asian-born). Results of the evaluation of assumptions of normality, homogeneity of variance-covariance matrices, linearity and multicollinearity were satisfactorily met.

Using Wilks' criterion, the combined dependent variables were significantly related to cultural background, $F$ (6, $191)=4.71, p<.001$, partial $\eta^{2}=0.07$. Within-cell marginal means for the dependent variables, adjusted for age, education and income, are given in Table 5.

Table 5. Within-cell marginal means for consumer decision-making styles

\begin{tabular}{lccccc}
\hline Cultural Background & \multicolumn{5}{c}{ Means for Consumer Decision-Making Styles } \\
\hline & $\begin{array}{c}\text { Perfectionist, high } \\
\text { quality conscious }\end{array}$ & $\begin{array}{c}\text { Brand } \\
\text { conscious }\end{array}$ & $\begin{array}{c}\text { Rational, price } \\
\text { conscious }\end{array}$ & $\begin{array}{c}\text { Confused by } \\
\text { overchoice }\end{array}$ & $\begin{array}{c}\text { Habitual, } \\
\text { brand loyal }\end{array}$ \\
Individualist & 4.38 & 3.09 & 4.56 & 3.16 & 3.33 \\
Collectivist & 4.33 & 3.58 & 4.69 & 3.49 & 3.52 \\
\hline
\end{tabular}

Univariate Fs showed that the only consumer decision-making styles that differed significantly across the cultural groups were confused by overchoice $F(1,196)=6.32 p<.05$, partial $\eta^{2}=0.03$ and brand conscious $F$ $(1,196)=19.28, p<.001$, partial $\eta^{2}=0.04$. There were no significant differences between these two groups on perfectionist, high quality conscious $F(1,196)=.16, p>.05$; rational, price conscious $F(1,196)=1.13, p>.05$; habitual, brand loyal $F(1,196)=2.14, p>.05$ consumer decision-making styles.

\section{Discussion and Managerial Implications}

The results of this research showed that there were no significant differences in the perfectionist, high quality conscious, price conscious, and habitual/brand loyal decision-making styles. In addition, the perfectionist and price conscious styles were highly used by both individualist and collectivist consumer groups. Consumers from both cultural groups expect a high standard of quality automobiles. Therefore, automobile companies need to use marketing messages which reflect on quality when promoting automobiles to both individualist and collectivist consumers. In the context of automobile purchases, properties such as risk may mean that all consumers approach purchase decisions more rationally and carefully. Marketing strategies need to focus on offering value for money, in addition to satisfying individualist and collectivist consumers' needs and wants.

Results also indicated that collectivist consumers are more brand conscious. This may be because they look for social approval from others, especially when making highly visible or high involvement purchases such as automobiles. Therefore, companies need to promote automobiles to collectivist consumers with strategies that 
highlight the significance of status and prestige. For collectivist consumers, status symbolises respect, consideration and envy from others. Marketing messages/information for collectivist consumers could focus heavily on the social approval and high prestige which consumers can gain by purchasing particular automobiles. Dealers could be trained (or from the same cultural background, if possible) to spend time explaining product features and benefits in full with collectivist consumers and their friends and family members whom they are likely to involve the final decision to purchase.

The current study also showed that collectivist consumers are confused by the information that they collect before making the automobile purchasing decision. Therefore, marketers need to provide similar, or even the same types of information/messages across different sources of information such as television advertisements, newspapers, billboards and magazines (de Mooij, 2004). The information/messages could include less information on mechanical and innovative features and focus on the prestige of the automobile. This could be a successful approach, if followed when developing strategies for collectivist consumers.

\section{Limitations}

Firstly, this study compared Australian and Asian consumers, based on the assumption that Westerners (Australians) are individualists and Easterners (Asian-born) are collectivists. Although, on average, Australian-born consumers scored higher on individualism and Asian-born consumers scored higher on collectivism, not all Australians scored higher on individualism and not all Asians scored higher on collectivism. Therefore, future research could split groups on the basis of cultural dimensions only, rather than on the basis of ethnic background, in order to obtain clearer results in relation to the effects of these dimensions.

Secondly, although this study compared consumers based on the cultural dimension of individualism-collectivism, there are other cultural dimensions that may also influence consumer decision-making styles. For example, Hofstede's masculine-feminine dimension may be related to styles such as fashion and price consciousness (Mitchell \& Walsh 2004). Future research could involve other cultural dimensions, such as masculine-feminine, power distance and long-term and short-term orientations, to distinguish their influences in consumer decision-making styles for automobile purchases.

\section{Conclusion}

There were no differences in individualism observed between Australian-born and Asian-born respondents; however there were differences in collectivism observed between Australian-born and Asian-born respondents, such that Asian-born respondents scored higher on collectivism. While there were some differences in the consumer decision-making styles of Australian-born versus Asian-born respondents, these differences were not accounted for by the cultural value dimensions of individualism and collectivism. Results indicated that Asian-born consumers scored significantly higher than Australian-born consumers on brand conscious and confused by overchoice decision-making styles. There were no significant differences between the two groups in terms of the perfectionist, high quality conscious; habitual/brand loyal and rational, price conscious decision-making styles. It is recommended that automobile companies consider developing programmed, carefully-targeted marketing strategies that appeal to individualist and collectivist consumers' decision-making styles and train their staff members, e.g., dealers, accordingly. These two groups seem to have distinct needs with which marketers might engage in matching their desired needs when designing new, or refining existing, automobiles. Improving the match between consumer needs and marketing strategies may improve the prediction of consumer behaviour, decreasing uncertainty for organisations, and giving marketing managers more confidence in their strategies. Greater insight into consumer behaviour may facilitate economic stability.

\section{References}

Aaker, J. L., \& Maheswaren, D. (1997). The effect of cultural orientation on persuasion. Journal of Consumer Research, 24, 315-328. http://dx.doi.org/10.1086/209513

Ackerman, D. T., \& Tellis, G. (2001). Can culture affect prices? A cultural study in shopping and retail prices. Journal of Retailing, 77, 57-82. http://dx.doi.org/10.1016/S0022-4359(00)00046-4

Alden, D. A., Hoyer, W. D., \& Lee, C. (1993). Identifying global and culture-specific dimensions of humor in advertising: a multinational analysis. Journal of Marketing, 57, 64-75. http://dx.doi.org/10.2307/1252027

Bauer, H. S., Sauer, N. E., \& Becker, C. (2006). Investigating the relationship between product involvement and consumer decision making styles. Journal of Consumer Behaviour, 5, 342-354. http://dx.doi.org/10.1002/cb.185 
Belk, R. W., Kenneth, D. H., \& Robert, N. M. (1982). Developmental recognition of consumption symbolism. Journal of Consumer Research, 9, 4-17. http://dx.doi.org/10.1086/208892

Blodget, J., Bakir, A., \& Rose, G. (2008). A test of the validity of hofstede's cultural framework. Journal of Consumer Marketing, 25, 339-349. http://dx.doi.org/10.1108/14635781111150312

Bond, M. H., Al Au, K. L., Tong, K., Carrrasquel, S. R., Murakami, F., Yamaguchi, S., \& Singelis, T. M. (2004). Culture-level dimensions of social axioms and their correlates across 41 cultures. Journal of Cross-Cultural Psychology, 35, 548-570. http://dx.doi.org/10.1177/0022022104268388

Byrne, B. M. (2001). Structural equation modeling with amos: basic concepts, applications, and programming. Mahwah, NJ: Lawrence Erlbaum.

Cowley, E. (2002). East-west consumer confidence and accuracy in memory for product information. Journal of Business Research, 55, 915-921. http://dx.doi.org/10.1016/S0148-2963(01)00211-9

Dann, J. S., \& Dann, S. (2003). Introduction to marketing. Milton, QLD: John Wiley.

De Mooij, M. (2004). Consumer behaviour and culture: consequences for global marketing and advertising. Thousand Oaks, CA: Sage.

De Mooij, M. (2010). Global marketing and advertising: understanding cultural paradoxes (3rd ed.). Singapore: Sage.

Doran, K. B. (2002). Lessons learnt in cross-cultural research of Chinese and North American consumers. Journal of Business Research, 55, 823-829. http://dx.doi.org/10.1016/S0148-2963(00)00222-8

Durvasula, S., Lysonski, S., \& Andrews, J. G. (1993). Cross-cultural generalizability of a scale for profiling consumers' decision making styles. Journal of Consumer Affairs, 27, 55-65. http://dx.doi.org/10.1111/j.1745-6606.1993.tb00737.x

Gregory, G. D., \& Munch, J. M. (1997). Cultural values in international advertising: an examination of familial norms and roles in Mexico. Psychology \& Marketing, 14, 99-119. http://dx.doi.org/10.1002/(SICI)1520-6793(199703)14:2<99::AID-MAR1>3.0.CO;2-I

Gurhan-Canli, Z., \& Maheswaran, D. (2000). Cultural variations in country of origin effects'. Journal of Marketing Research, 37, 309-317.

Hafstrom, J. J., Chae, J. S., \& Chung, Y. S. (1992). Consumer decision making styles: Comparison between United States and Korean young consumers. Journal of Consumer Affairs, 26, 146-158. http://dx.doi.org/10.1111/j.1745-6606.1992.tb00020.x

Hanzaee, K. H., \& Aghasibeig, S. (2008). Generation Y female and male decision making styles in Iran: are they different? International Review of Retail, Distribution and Consumer Research, 18, 521-537. http://dx.doi.org/10.1080/09593960802573443

Hassay, D. N., \& Smith, M. C. (1996). Compulsive buying: An examination of the consumption motive. Psychology \& Marketing, 741-752. http://dx.doi.org/10.1002/(SICI)1520-6793(199612)13:8<741::AID-MAR2>3.0.CO;2-F

Hiu, A. S. Y., Siu, N. Y. M., Wang, C. C. L., \& Chang, L. M. K. (2001). An investigation of decision making styles of consumers in China. Journal of Consumer Affairs, 35, 326-345. http://dx.doi.org/10.1111/j.1745-6606.2001.tb00117.x

Hofstede, G. (2001). Culture's consequences: comparing values behaviours, institutions and organisations across nations. London: Sage.

Hui, C. H. (1998). Measurement of individualism and collectivism. Journal of Research in Personality \& Social Psychology, 22, 17-36.

Kacen, J. J., \& Lee, J. A. (2002). The influence of culture on consumer impulsive buying behaviour. Journal of Consumer Psychology, 12, 163-176. http://dx.doi.org/10.1207/S15327663JCP1202_08

Kim, J., Forsythe, S., Gu, Q., \& Moon, S. J. (2002). Cross-cultural consumer values, needs and purchase behaviour. Journal of Consumer Marketing, 19, 481-502. http://dx.doi.org/10.1108/07363760210444869

Leo, C., Bennett, R., \& Hartel, E. J. (2005). Cross-cultural differences in consumer decision making styles. Cross Cultural Management, 12, 32-61. http://dx.doi.org/10.1108/13527600510798060

Liu, R. R., \& McClure, P. (2001). Recognizing cross-cultural differences in consumer complaint behaviour and 
intentions: An empirical examination. Journal of Consumer Marketing, 18, 54-75. http://dx.doi.org/10.1108/07363760110365813

Lysonski, S., Durvasula, S., \& Zotos, Y. (1996). Consumer decision making styles: a multi country investigation. European Journal of Marketing, 30, 10-21. http://dx.doi.org/10.1108/03090569610153273

Manrai, L. A., Lascu, D., Manrai, A. K., \& Babb, H. W. (2001). A cross-cultural comparison of style in Eastern European emerging markets. International Marketing Review, 18, 270-285. http://dx.doi.org/10.1108/02651330110396479

Manrai, L. A., \& Manrai, A. K. (1996). Global perspective in cross-cultural and cross national consumer research. Binghamton, NY: International Business Press.

Mattila, A. S., \& Patterson, P. (2004). The impact of culture on consumers' perceptions of service recovery efforts. Journal of Retailing, 80, 196-206. http://dx.doi.org/10.1016/j.jretai.2004.08.001

Miller, P. W., \& Volker, P. (1985). Economic progress in Australia: An analysis of occupational mobility. Economic Record, 61, 463-475. http://dx.doi.org/10.1111/j.1475-4932.1985.tb01998.x

Mitchell, V. W., \& Bates, L. (1998). UK consumer decision making styles. Journal of Marketing Management, 14, 199-225. http://dx.doi.org/10.1362/026725798784959345

Mogelonsky, M. (1998). Keep candy in the aisle. Journal of Social Issues, 20, 20-32.

Nunally, J. C. (1978). Psychometric Theory (2nd ed.). NY: McGraw-Hill Book Company.

Omar, W. M., Ali, M. M., Hussin, Z., \& Rahim, A. H. (2009). Decision orientations towards shopping and buying among young adult Malays in the universities. International Journal of Business \& Management, 4 , 26-30.

Park, C., \& Kim, Y. (2003). Identifying key factors affecting consumer purchase behaviour in an online shopping context. International Journal of Retail \& Distribution Management, 31, 16-29. http://dx.doi.org/10.1108/09590550310457818

Phau, I., \& Lau, K. C. (2001). Brand personality and consumer self-expression: single or dual carriageway? Brand Management, 8, 428-444. http://dx.doi.org/10.1057/palgrave.bm.2540042

Phau, I., Teah, M., \& Lee, A. (2009). Targeting buyers of counterfeits of luxury brands: A study on attitudes of Singaporean consumers. Journal of Targeting, Measurement \& Analysis for Marketing, 17, 3-15. http://dx.doi.org/10.1057/jt.2008.25

Radder, L., Li, Y., \& Pieterson, J. J. (2006). Decision making styles of young Chinese, Motswana and Caucasian consumers in South Africa: An exploratory study. Journal of Family Ecology and Consumer Sciences, 34, 20-31.

Roth, M. S. (1995). Effects of global market conditions on brand image customization and brand performance. Journal of Advertising, 24, 55-75.

Satish, S. M., \& Bharadwaj, S. (2010). Information search behaviour among new car buyers: a two-step cluster analysis. IIMB Management Review, 22, 5-15. http://dx.doi.org/10.1016/j.iimb.2010.03.005

Singelis, T. M., Triandis, H. C., Bhawuk, D. P. S., \& Gelfand, M. J. (1995). Horizontal and vertical dimensions of individualism and collectivism: a theoretical and measurement refinement. Cross-cultural Research, 29, 240-275. http://dx.doi.org/10.1177/106939719502900302

Singh, S. (2006). Cultural differences in, and influences on, consumers' propensity to adopt innovations. International Marketing Review, 23, 173-191. http://dx.doi.org/10.1108/02651330610660074

Soars, A. M., Farhangmehr, M., \& Shoham, A. (2007). Hofstede's dimensions of culture in international marketing studies. Journal of Business Research, 60, 277-284. http://dx.doi.org/10.1016/j.jbusres.2006.10.018

Sproles, G. B. (1983). Conceptualisation and Measurement of Optimal Consumer Decision Making. Journal of Consumer Affairs, 17, 421-438. http://dx.doi.org/10.1111/j.1745-6606.1983.tb00312.x

Sproles, G. B., \& Kendall, E. L. (1986). A methodology of profiling consumer decision making styles. Journal of Consumer Affairs, 20, 267-279. http://dx.doi.org/10.1111/j.1745-6606.1986.tb00382.x

Steenkamp, J. E. M., Hofstede, F., \& Wedel, M. (1999). A cross-national investigation into the individual and national cultural antecedents of consumer innovativeness. Journal of Consumer Marketing, 63, 55-69. 
Triandis, H. C. (1995). Self description and cultural values scale; individualism and collectivism. Boulder, Westview Press.

Triandis, H. C. (2008). Towards the realistic perception of a culture. Social \& Personality Psychology Compass, 2, 1812-1823. http://dx.doi.org/10.1111/j.1751-9004.2008.00149.x

Veroplanken, B., \& Herabadi, A. (2001). Individual differences in impulse buying tendency: feeling and no thinking. European Journal of Personality, 15, 71-83. http://dx.doi.org/10.1002/per.423

Vohs, K. D., \& Faber, R. J. (2007). Spent resources: self-regulatory resource availability affects impulse buying. Journal of Consumer Research, 33, 537-547. http://dx.doi.org/10.1086/510228

Wagner, J. A., \& Moch, M. K. (1986). Individualism and collectivism: Concept and measure. Group Organization Management, 11, 280-304. http://dx.doi.org/10.1177/105960118601100309

Watson, J. J., \& Wright, K. (2000). Consumer ethnocentrism and attitudes toward domestic and foreign products. European Journal of Marketing, 34, 1149-1166. http://dx.doi.org/10.1108/03090560010342520

Wong, N. Y., \& Ahuvia, A. C. (1998). Personal taste and family face: luxury consumption in Confucian and $\begin{array}{lllll}\text { western societies. } \quad \text { Psychology } \quad \text { \& } & \text { Marketing, } & 15,\end{array}$ http://dx.doi.org/10.1002/(SICI)1520-6793(199808)15:5<423::AID-MAR2>3.0.CO;2-9 